\title{
Lead compounds in bottom sediments of the Seversky Donets floodplain
}

\author{
Marina Burachevskaya, ${ }^{*}$, Dina Nevidomskaya, Victoria Tsitsuashvili, Vishnu Rajput, and \\ Dmitry Bren
}

Southern federal university, Academy of biology and biotechnology, 344090 Rostov-on-Don, Russia

\begin{abstract}
Investigations on heavy metals in water bodies are extremely important in a comprehensive assessment when the anthropogenic activities disturb the natural environment. The present paper studies the composition of $\mathrm{Pb}$ compounds in highly contaminated bottom sediments of a natural settling basin of a chemical plant at the Atamanskoye lake in the floodplain of the Seversky Donets River by sequential fractionation. The predominance of the residual $\mathrm{Pb}$ fraction, which is represented by layered silicates (hydromuscovite, montmorillonite, kaolinite) is shown. Organic matter and Fe-Mn (hydr)oxides also play an important role in metal interaction. High mobility of $\mathrm{Pb}$ is noted, which associated with imposing high environmental risks in the studied area.
\end{abstract}

\section{Introduction}

Large enterprises of the chemical industry exert great pressure on the environment through their emissions including gaseous, liquid, and solid wastes. The most hazardous pollutants which are entering into terrestrial and aquatic ecosystems daily are heavy metals. Despite organic pollutants undergoing degradation processes, metals are only capable of redistribution between the individual components of water systems and the environment; thus remaining in the environment. In this regard, particular attention must be paid to floodplain landscapes, due to their position placed at the lower part of the cascade landscape-geochemical system to collect heavy metals $[1,2,3]$. Bottom sediments are considered to be an integral indicator of the man-caused load on the water body. In this case, bottom sediments are a kind of depot for heavy metals, keeping the long-term anthropogenic impact on the ecosystem. A change in the physicochemical equilibrium in aqueous solutions can provoke the secondary contamination of adjacent media, taking into account that the buffer capacity of bottom sediments (especially that of the upper layers) is limited.

The toxicity of an element is determined by the form of its location, as well as the composition and properties of the deposit medium $[4,5]$. Chemical methods of sequential extraction are widely used to evaluate the forms of metal compounds in soils and bottom sediments $[3,6,7,8]$.

\footnotetext{
* Corresponding author: marina.0911@mail.ru
} 
The purpose of the paper was to study the fractional composition of $\mathrm{Pb}$ in highly polluted bottom sediments. $\mathrm{Pb}$ belongs to the class I environmental hazard, hence it becomes very important to study its mobility and concentration in the highly contaminated bottom sediments.

\section{Materials and methods}

Sampling was done in the bottom sediments located at the Atamanskoye lake in the floodplain of the Seversky Donets River, the main tributary of the Don River. The study area experiences many years of anthropogenic stress due to more than 40 years serving as a natural settling basin for enterprises in the industrial area of Kamensk-Shakhtinsky, Rostov Region. According to the literature report [9], there are 180 thousand tons of flowing sludge, 343 thousand tons of stiff sludge, and more than 444 thousand tons of soft plastic sludge in the lake. All of the above deposits are contaminated with several metals and metalloids, such as $\mathrm{As}, \mathrm{Li}, \mathrm{Hg}, \mathrm{Cd}, \mathrm{Zn}, \mathrm{Cu}, \mathrm{Pb}, \mathrm{Sn}, \mathrm{Mn}, \mathrm{Cr}$, as well as organometallic compounds. The physic-chemical characteristics and the total metal content in the sample of bottom sediments are presented in Tables 1 and 2 . The study of the properties of bottom sediments was carried out by generally accepted methods [5]. The total content of $\mathrm{Pb}$ in the samples was determined by $\mathrm{x}$-ray fluorescence method.

Table 1. Physico-chemical properties of bottom sediments (aleuropelitic silt, surface horizon)

\begin{tabular}{|c|c|c|c|c|c|c|}
\hline Corg, \% & pHн20 & $\begin{array}{c}\text { Silt and clay } \\
(<\mathbf{0 . 0 1} \mathbf{~ m m}), \\
\mathbf{\%}\end{array}$ & $\begin{array}{c}\text { Silt }(<\mathbf{0 . 0 0 1} \\
\mathbf{m m}) \mathbf{\%}\end{array}$ & $\begin{array}{c}\text { CEC, } \\
\mathbf{c m o l} / \mathbf{k g}\end{array}$ & $\begin{array}{c}\mathbf{C a C O}_{3}, \\
\mathbf{\%}\end{array}$ & $\begin{array}{c}\mathbf{M g C O}_{3}, \\
\mathbf{\%}\end{array}$ \\
\hline 4.1 & $8.3 \pm 0.8^{*}$ & 69.6 & 17.6 & $21.3 \pm 2.0$ & 1.8 & 0.9 \\
\hline
\end{tabular}

$* \pm$ Standard deviation

Table 2. Total chemical composition of bottom sediments (aleuropelitic silt, surface horizon), $\mathrm{mg} / \mathrm{kg}$

\begin{tabular}{|c|c|c|c|c|c|c|c|}
\hline $\mathbf{S i O}_{2}$ & $\mathbf{A l}_{2} \mathbf{O}_{3}$ & $\mathbf{F e}_{2} \mathbf{O}_{3}$ & $\mathbf{C a O}$ & $\mathbf{M g O}$ & $\mathbf{K}_{\mathbf{2}} \mathbf{O}$ & $\mathbf{P}_{\mathbf{2}} \mathbf{O}_{\mathbf{5}}$ & $\mathbf{P b}$ \\
\hline 51.8 & 8.9 & 3.2 & 12.1 & 2.2 & 1.5 & 0.3 & 1580 \\
$\pm 5.4^{*}$ & \pm 0.8 & \pm 0.2 & \pm 1.1 & \pm 0.1 & \pm 0.1 & \pm 0.001 & \pm 120 \\
\hline
\end{tabular}

$* \pm$ Standard deviation

Sequential extraction can assess the degree of contamination and, hence, the contamination hazard level. Furthermore, these methods meet all the necessary requirements for implementation over a wide area: simple, applicable to all kinds of sediments, low cost, and easily understandable and comparable results. To study the composition of $\mathrm{Pb}$ compounds in bottom sediments the Tessier sequential fractionation method was used [8]. This widely-known method is often used to assess the fractional composition of heavy metals. It is initially focused on the analysis of bottom sediments and provides the isolation of five fractions of metal compounds: exchangeable $\left(1 \mathrm{M} \mathrm{MgCl}_{2}\right)$, bound to carbonates $\left(1 \mathrm{M} \mathrm{CH}_{3} \mathrm{COONa}\right)$, bound to Fe-Mn (hydr)oxides $\left(0.04 \mathrm{M} \mathrm{NH}_{2} \mathrm{OH} \cdot \mathrm{HCl}\right.$ in $\left.25 \% \mathrm{CH}_{3} \mathrm{COOH}\right)$, bound to organic matter $\left(0.02 \mathrm{M} \mathrm{HNO}_{3}+30 \% \mathrm{H}_{2} \mathrm{O}_{2}\right.$, pH 2 , then 3.2

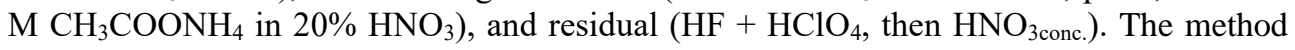
provides detailed information on the nature, occurrence forms, biological and physicochemical activity, mobility, and transportation of metal. The analysis of the $\mathrm{Pb}$ content in the extracts was carried out by atomic absorption spectrophotometry (AAS).

The tests were made in triplicate. Statistical data were done using the STATISTICA 2010 program. 


\section{Results and discussion}

Content of in $\mathrm{Pb}$ the study samples located on the territory of the natural settling basin of the industrial wastewater of the chemical plant, exceeds in 158 -fold the clarke by the metal $(10 \mathrm{mg} / \mathrm{kg})$ in the lithosphere was detected [10] (Table 2).

Fractionation of $\mathrm{Pb}$ compounds in the study sample of bottom sediments was shown in Table 3. The dominance of the residual fraction ( $49 \%$ of the total content of all fractions) could be inferred from the data. This fraction contains mainly primary and secondary minerals, which may hold trace metals with in their crystal structure [8]. Mineralogical analysis [11] showed the predominance of layered silicates (hydromuscovite, montmorillonite and kaolinite) (Table 4). Layer silicates are characterized by the chemical and energetic heterogeneity of their surface, which is characterized by the presence of structural defects and functional groups of different composition, which could serve as active centers during metal absorption. Such centers are frequently exchangeable cations, surface hydroxyl groups, and oxygen of the tetrahedral sheet. The application of XANES and EXAFS methods makes it possible to identify the heavy metals presence in the octahedral structure of layer silicates [12, 13, 14].

Table 3. Fractional composition of $\mathrm{Pb}$ compounds in contaminated bottom sediments, $\mathrm{mg} / \mathrm{kg}$

\begin{tabular}{|c|c|c|c|c|}
\hline \multicolumn{5}{|c|}{ Fractions } \\
\hline Exchangeable & $\begin{array}{c}\text { Bound to } \\
\text { carbonates }\end{array}$ & $\begin{array}{c}\text { Bound to Fe-Mn } \\
\text { (hydr)oxides }\end{array}$ & $\begin{array}{c}\text { Bound to organic } \\
\text { matter }\end{array}$ & Residual \\
\hline $287 \pm 30^{*}$ & $100 \pm 11$ & $187 \pm 19$ & $196 \pm 22$ & $769 \pm 72$ \\
\hline
\end{tabular}

* \pm Standard deviation

Table 4. The mineralogical composition of the residual fraction in contaminated bottom sediments, $\%$

\begin{tabular}{|c|c|c|c|c|}
\hline \multicolumn{5}{|c|}{ Minerals } \\
\hline Quartz & Feldspar & Hydromuscovite & Montmorillonite & Kaolinite \\
\hline 5.0 & 5.0 & 58.3 & 19.0 & 12.7 \\
\hline
\end{tabular}

Metals may be bound to various forms of organic matter: living organisms, detritus, coatings on mineral particles, etc. The complexation and peptization properties of natural organic matter (notably humic and fulvic acids) are well recognized, as is the phenomenon of bioaccumulation in certain living organisms [8]. The fraction associated with organic matter accounts for $13 \%$ (Fig. 1). Pb has a high ability to form strong chelate complexes with organic matter $[14,15]$. This is evidenced by the stability constants of metal complexes with humic acids, which determine the high organophilicity towards the metal [16].

The fraction bound to carbonate is the lowest and does not exceed 7\% (Table 3). Metals can be co-precipitated by carbonates, enter in their structure, or be sorbed on Fe-Mn oxides, which are deposited on the surface of carbonates [14].

It is noted that $\mathrm{Pb}$ bound to Fe and $\mathrm{Mn}$ (hydr)oxides - 12\% (Table 3). Oxides and hydroxides play an extremely important role in the fixation of heavy metals $[16,17]$. Fe oxides and hydroxides have a large active surface due to the ability to form polymolecular films on the surface of secondary clay minerals. Heavy metals ions interact by displacing $\mathrm{H}^{+}$ions that enter $\mathrm{OH}^{-}$or $\mathrm{OH}^{2-}$ groups on the oxide surface, or by substitution $\mathrm{Fe}^{3+}$ or $\mathrm{Fe}^{2+}$ ions, which probably determines the state of many metals [18].

Chemical fractionation showed high values of $\mathrm{Pb}$ content in the exchangeable fraction (287 $\mathrm{mg} / \mathrm{kg}$ or $19 \%$ of the total fractions), which is 48 times higher than the maximum permissible concentration of the mobile metal $(6.0 \mathrm{mg} / \mathrm{kg})$ [19] (Table 3, Fig. 1). Exchangeable metals are fixed mainly by electrostatic forces on the surface of clay and 
other minerals, amorphous compounds and organic substances with a low pH [15]. These are the most mobile metal forms. This indicates a large environmental risk to adjacent landscapes.

\section{Conclusions}

The sequence of distribution of $\mathrm{Pb}$ among the fractions were found to be in the order as follows: residual > bound to $\mathrm{Fe}$ and $\mathrm{Mn}$ (hydr)oxides = bound to organic matter > exchangeable $>$ bound to carbonates.

The mobility of $\mathrm{Pb}$ is quite high (19\%) in highly polluted bottom sediments, which is the most dangerous consequence of pollutions entered the area by enterprise emissions. The main stabilizers of $\mathrm{Pb}$ mobility are layered silicates (hydromuscovite, montmorillonite, kaolinite), organic matter, and Fe and Mn (hydr)oxides.

The study was supported by the Russian Science Foundation grant, project No. 19-74-00085.

\section{References}

1. L. Zhang, X. Ye, H. Feng, Y. Jing, T. Ouyang, X. Yu, R. Liang, C. Gao, W. Chen, Marine pollution Bulletin, 54(7), 974-982 (2007)

2. A.D. Dukes, R.T. Eklund, Z.D. Morgan, R.C. Layland, Water, Air, \& Soil Pollution, 231, 11 (2020)

3. A. Malsiu, I. Shehu, T. Stafilov, F.Faiku, J. of Environ. and Public Health, ID 3098594 (2020)

4. A. Manceau, M.A. Marcus, N. Tamura, Rev. Mineral Geochem., 49, 341-428 (2002)

5. P.I. Kurilov, R.P. Kruglyakova, N.I. Savitskaya, P.S. Fedotov, J. of Anal. Chem., 64(7), 738-745 (2009)

6. T.M. Minkina, G.V. Motuzova, O.G. Nazarenko, V.S. Kryshchenko, S.S. Mandzhieva, Eur. Soil Sci., 41(7), 708-716 (2008)

7. T.M. Minkina, G.V. Motusova, O.G. Nazarenko, S.S. Mandzhieva, Heavy metal compounds in soil: transformation upon soil pollution and ecological significance (Nova Science Publishers Inc., 2010)

8. A. Tessier, P.G.C. Campbell, M. Bisson, Anal Chem., 51, 844-850 (1979)

9. V. V. Privalenko, Study of the regime of pollution of underground water and the environment at the experimental production site in the area of Kamensk-Shakhtinsky in 1993-1997 (report of the engineering and geological party of the Rostov GRE) (Rostov-on-Don, 1998) (in Russian)

10. A.P. Vinogradov, Geochemistry of rare and dispersed chemical elements in soils (Moscow, RAN, 1957) (in Russian)

11. Methodological Recommendations of the Scientific Council on the Methods of Mineralogical Studies (no. 158. Moscow, 2008) (in Russian).

12. J. Myers, K. Thorbjornsen, Soil Sediment Cont. 13, 1-16 (2004).

13. M. J. Kwon, M. I. Boyanov, J. S. Yang, S. Lee, Y. H. Hwang, J. Y. Lee, B. Mishra, and K. M. Kemner, Environ. Pollut. 226, 346-355 (2017).

14. D.G. Nevidomskaya, T.M. Minkina, A.V. Soldatov, V.A. Shuvaeva, Y.V. Zubavichus, Yu.S. Podkovyrina, J. Soils and Sedim., 16(4), 1183-1192 (2016)

15. D.L. Pinskii, T.M. Minkina, Eur. J. Soil Sci., 2, 59-68 (2013) 
16. A. Kabata-Pendias, Trace elements in soil and plants (Boca Raton, London, N.Y., CRC Press, 2011)

17. E.V. Mellis, J.C. Casagrande, M.C.P. Cruz, Conf. proc. 7th international Conference on the Biogeochemistry of Trace Elements, V.III, 20-21 (Uppsala, Sweden, 2003)

18. I.O. Plekhanova, ,O.V. Klenova, Y.D. Kutukova, Eur. Soil Sci., 34, 496-503 (2001)

19. GN 2.1.7.2041-06. Maximum permissible concentrations of chemicals in the soil: Hygiene standards (Rospotrebnadzor, Moscow, 2006) (in Russian) 